\title{
FAKTOR DITERMINAN YANG DAPAT MEMPREDIKSI PERUBAHAN STRUKTUR MODAL (Studi Empiris pada Perusahaan Sub Sektor Perkebunan yang Terdaftar di Bursa Efek Indonesia)
}

\author{
Slamet Mudjijah \\ Dosen pada Program Studi Manajemen Universitas Budi Luhur \\ Email : Slamet.mudjijah@budiluhur.ac.id
}

\begin{abstract}
The purpose of this study is to analyze the factors that can predict changes in capital structure. The population in this research is the Sub Sector Company of Plantation listed in Indonesia Stock Exchange. Determination of sample using purposive sampling technique. Sample used 11 (eleven) companies in Sub Sector Plantation. This study uses secondary data, in the form of Financial Statements for 2012-2016. Research data is processed using SPSS 20.0 software, with data processing method that includes classical assumption test and hypothesis test. The results showed that profitability and liquidity were able to predict negatively on the capital structure of plantation sub-sector companies, while business risk was not able to predict capital structure.
\end{abstract}

Keywords: Profitability, Liquidity, Business Risk, Capital Structure

\begin{abstract}
ABSTRAK
Tujuan penelitian ini untuk menganalisis faktor-faktor yang dapat memprediksi perubahan struktur modal. Populasi dalam penelitian in adalah Perusahaan Sub Sektor Perkebunan yang terdaftar Di Bursa Efek Indonesia. Penentuan sampel menggunakan teknik purposive sampling. Sampel yang digunakan 11 (sebelas) perusahaan pada Sub Sektor Perkebunan. Penelitian ini menggunakan data sekunder, berupa Laporan Keuangan tahun 2012-2016. Data penelitian diolah menggunakan perangkat lunak SPSS 20.0, dengan metode pengolahan data yang meliputi uji asumsi klasik dan uji hipotesis. Hasil penelitian menunjukkan bahwa profitabilitas dan liquiditas mampu memprediksi secara negatif terhadap struktur modal pada perusahaan sub sektor perkebunan, sedangkan Risiko Bisnis tidak mampu memprediksi struktur modal.
\end{abstract}

Kata Kunci : profitabilitas, liquiditas, risiko bisnis, struktur modal

\section{A. PENDAHULUAN}

Indonesia dikenal sebagai negara agraris karena sebagian besar penduduk Indonesia mempunyai pencaharian di bidang pertanian atau bercocok tanam. Pertanian di Indonesia menghasilkan berbagai macam tumbuhan komoditi ekspor, 
antara lain padi, jagung,kedelai, sayur-sayuran, cabai, ubi, dan singkong. Di samping itu, Indonesia juga dikenal dengan hasil perkebunannya, antara lain: karet, kelapa sawit, tembakau, kapas. Perusahaan sub sektor perkebunan mempunyai peranan penting dalam pembangunan perekonomian di Indonesia, karena sub sektor Perkebunan merupakan salah satu penyumbang terbesar ekspor bagi pendapatan devisa negara dan penyedia lapangan pekerjaan.

Seiring dengan perekonomian yang selalu mengalami perubahan dan persaingan bisnis yang semakin kompetitif, perusahaan perkebunan dituntut untuk selalu berkembang dan mempertahankan eksistensinya. Terjaganya eksistensi suatu perusahaan diantaranya tergantung pada kemampuan perusahaan tersebut untuk melihat peluang-peluang bisnis yang ada. Selain itu untuk mengantisipasi persaingan global, maka industri perkebunan di Indonesia perlu meningkatkan kualitas produknya sebagai strategi bisnis agar tetap eksis dan kompetitif. Daya saing perusahaan perkebunan harus didukung dengan keputusan pendanaan yang tepat melalui perancangan struktur modal yang tepat. Pendanaan dibutuhkan oleh perusahaan guna membiayai kegiatan operasional maupun ekspansinya. Dana dapat berasal dari sumber internal dan eksternal perusahaan. Sumber internal yaitu dana yang dihasilkan sendiri oleh perusahaan berupa laba yang di tahan dan akumulasi depresiasi, sedangkan sumber eksternal yaitu dana yang dihasilkan dari luar perusahaan berupa dana dari kreditur dan pemilik. Perusahaan harus mampu menghimpun dana baik yang bersumber dari dalam maupun luar perusahaan secara efisien, oleh karena itu perlu adanya keseimbangan yang optimal antara kedua sumber dana tersebut. Salah satu keputusan penting yang di hadapi perusahaan dalam kaitannya dengan operasi perusahaan adalah keputusan atas struktur modal, yaitu gambaran dari bentuk proporsi finansial perusahaan antara modal yang dimiliki yang bersumber dari utang jangka panjang (long-term liabilities) dan modal sendiri (shareholder' equity) yang menjadi sumber pembiayaan suatu perusahaan (Fahmi, 2016).

Struktur modal merupakan hal yang penting diperhatikan dan di analisa karena struktur modal dapat menggambarkan resiko jangka panjang yang ditanggung perusahaan selama perusahaan itu beroperasi. Untuk dapat memutuskan struktur modal, manajemen perusahaan hendaknya memahami faktor-faktor yang dapat berpengaruh terhadap struktur modal. Faktor-faktor tersebut dapat dijadikan sebagai dasar pertimbangan untuk menentukan komposisi struktur modal perusahaan. Penelitian ini bertujuan untuk menguji tiga faktor yang mempengaruhi struktur modal, yaitu tingkat profitabilitas, liquiditas, risiko bisnis. Para peneliti sebelumnya menghasilkan kesimpulan yang masih belum konsisten berkaitan dengan factor-faktor penentu struktur modal. Hasil studi empiris pada perusahaan di Kroasia menunjukkan bahwa liquiditas berkorelasi negatif dengan struktur modal (Šarlija \& Harc, 2012). Korelasi positif antara liquiditas dengan struktur modal ditemukan pada perusahaan public di bidang manufaktur dan jasa di Kuwait (Gharaibeh, 2015).

Profitabilitas dapat meningkatkan sumber pendanaan internal bagi perusahaan. Hasil penelitian empiris menunjukkan profitabilitas berkorelasi negatif dengan struktur modal (Gharaibeh, 2015), (Kakilli Acaravci, 2015). Namun studi empiris pada perusahaan publik sektor jasa di China menunjukkan 
hasil yang berbeda yaitu profitabilitas tidak berkorelasi dengan struktur modal (Lim, 2012).

Risiko perusahaan ditanggung oleh perusahaan karena adanya ketidakpastian lingkungan bisnis(Alnajjar, 2015) . Kesimpulan atas studi empiris bahwa risiko bisnis berkorelasi negatif dengan struktur modal ditemukan pada perusahaan sektor industri di Yordania (Alnajjar, 2015). Berbeda dengan Alnajjar, korelasi positif antara risiko bisnis dengan struktur modal ditemukan pada pada perusahaan publik sektor farmasi di Indonesia (Djaddang \& Ghozali, 2017).

\section{B. KAJIAN PUSTAKA}

Pengambilan keputusan terkait struktur modal perlu dilakukan secara efektif dan efisien, agar mampu menciptakan struktur modal yang optimal. Kombinasi hutang dan ekuitas dapat berimplikasi pada nilai perusahaan dan biaya modal (Abeywardhana, 2017). Dalam memaksimalkan kekayaan perusahaan pemegang saham menghendaki penggunaan lebih banyak modal utang dalam struktur modal karena bunga yang dibayarkan menyebabkan pengurangan pajak dan menurunkan biaya efektif utang. Pemegang saham tidak harus membagi keuntungan mereka dengan pemegang utang karena pemegang utang mendapatkan pengembalian tetap. Namun, semakin tinggi modal hutang, semakin beresiko perusahaan, maka semakin tinggi biaya modalnya. Oleh karena itu penting untuk mengidentifikasi unsur-unsur penting dari struktur modal, ukuran yang tepat dari elemen-elemen ini dan struktur modal terbaik untuk suatu perusahaan tertentu pada waktu tertentu.

Dengan demikian untuk melakukan pengambilan keputusan struktur modal, perusahaan hendaknya memperhatikan faktor-faktor yang memprediksi struktur modal.

\section{Teori Struktur Modal : The Trade-Off And Pecking Order Theories}

Hubungan antara keputusan struktur modal dan nilai perusahaan telah banyak diteliti dalam beberapa dekade terakhir. Selama bertahun-tahun, teori struktur modal alternatif telah dikembangkan untuk menentukan faktor-faktor yang mempengaruhi keputusan struktur modal. Modigliani dan Miller adalah tonggak sejarah di antara studi struktur modal. Modigliani dan Miller (1958) menyatakan bahwa "In their first proposition state that market is fully efficient when there are no taxes. Thus, capital structure and financing decisions affect neither cost of capital nor market value of a firm. In their second proposition, they maintain that interest payments of debt decrease the tax base, thus cost of debt is less than the cost of equity" (Myers, 2001).

Keuntungan pajak dari hutang memotivasi teori struktur modal yang optimal, yang menyiratkan bahwa perusahaan dapat mencapai struktur modal yang optimal dan meningkatkan nilai perusahaan dengan mengubah struktur permodalan mereka. Bangkrut dan kesulitan keuangan merupakan dasar teori trade-off (Myers, 2001). Teori trade-off menegaskan bahwa perusahaan menetapkan target utang untuk menilai rasio dan secara bertahap bergerak ke arah itu. Menurut teori ini, setiap kenaikan tingkat hutang menyebabkan kenaikan kebangkrutan, tekanan keuangan dan biaya agensi, dan karenanya menurunkan nilai perusahaan. Dengan demikian, struktur modal yang optimal dapat dicapai 
dengan menetapkan keseimbangan antara keuntungan (keuntungan pajak) dan kerugian (kesulitan keuangan dan biaya kebangkrutan) atas hutang. Untuk menetapkan keseimbangan ini perusahaan harus mencari tingkat hutang di mana biaya kesulitan keuangan mungkin mengimbangi keuntungan pajak dari peningkatan hutang.

Alternatif teori trade-off adalah teori pecking order berasumsi bahwa ada asimetri informasi antar investor (Myers, 2001). Investor umumnya memiliki informasi lebih sedikit daripada orang dalam, saham biasa akan diremehkan oleh pasar. Apalagi perusahaan tidak memiliki struktur modal sasaran. Teori pecking order menyatakan bahwa perusahaan lebih memilih pembiayaan eksternal internal dan hutang terhadap ekuitas, jika mereka menerbitkan sekuritas. Ketika perusahaan menggunakan dana eksternal, mereka lebih memilih untuk mengeluarkan keamanan teraman, yaitu utang, sekuritas konversi, dan ekuitas sebagai upaya terakhir. Mereka menggunakan dana eksternal hanya jika dana internal mereka tidak mencukupi.Teori trade-off menggaris-bawahi pajak, sementara teori pecking order menekankan informasi asimetris. Beberapa penelitian menyelidiki validitas empiris teori-teori ini. Dalam studi ini, struktur modal perusahaan terkait dengan faktor-faktor seperti profitabilitas, liquiditas dan risiko bisnis. Faktor-faktor ini dijelaskan secara singkat di bawah ini.

\section{Liquiditas}

Liquiditas menunjukkan kemampuan perusahaan untuk membayar kewajiban finansial jangka pendek tepat pada waktunya. Likuiditas perusahaan ditunjukkan oleh besar kecilnya aktiva lancar yaitu aktiva yang mudah untuk diubah menjadi kas. Aktiva lancar meliputi kas, surat berharga, piutang, persediaan. Suatu analisis likuiditas penuh membutuhkan penggunaan anggaran kas, tetapi dengan menghubungkan kas dan aset lancar lainnya dengan kewajiban lancar, analisis rasio memberikan ukuran likuiditas yang cepat dan mudah digunakan (Brigham, 2011). Current ratio sebagai salah satu cara untuk mengukur likuiditas perusahaan. "The current ratio is a widely used measure for evaluating a company's liquidity and short-term debt-paying ability. The ratio is computed by deviding current assets by current liabilities" (Weygandt, Jerry J., Paul D. Kimmel, 2012). Dengan kata lain rasio ini menggambarkan seberapa besar jumlah ketersediaan aktiva lancar yang dimiliki oleh perusahaan dibandingkan dengan total kewajiban (hutang) lancarnya. Rasio lancar dihitung sebagai hasil bagi antara total aset lancar dengan total kewajiban (hutang) lancar. Pecking order theory menyatakan bahwa perusahaan akan lebih memilih menggunakan pendanaan dari internal perusahaan. Perusahaan yang mempunyai current ratio yang tinggi akan mengurangi pendanaaan melalui utang. Hal ini disebabkan karena perusahaan sudah memiliki pendanaan sumber internal yang tinggi melalui aset yang likuid, maka semakin tinggi tingkat current ratio suatu perusahaan akan menurunkan penggunaan dana eksternal perusahaan. Dapat disimpulkan bahwa current ratio berpengaruh negatif terhadap struktur modal. Hal ini mendukung penelitian sebelumnya yang menunjukkan bahwa liquiditas berkorelasi negatif dengan struktur modal (Šarlija \& Harc, 2012). 
H1 : Peningkatan liquiditas dapat memprediksi penurunan struktur modal.

\section{Profitabilitas}

Profitabilitas merupakan hubungan antara pendapatan dan biaya yang dihasilkan dengan menggunakan aset perusahaan, baik lancar maupun tetap, dalam aktivitas produksi. Profitabilitas dapat dinilai dengan berbagai cara, salah satunya adalah menggunakan rasio. Rasio profitabilitas adalah rasio yang digunakan untuk mengukur efektifitas manajemen berdasarkan hasil pengembalian dari penjualan investasi serta kemampuan perusahaan menghasilkan laba yang akan menjadi dasar pembagian dividen perusahaan. (Gitman, 2012). Rasio yang lazim digunakan untuk mengukur profitabilitas antara lain Return on Assets. "An overall measure of profitability is return on assets. We compute this ratio by dividing net income by average assets" (Weygandt, Jerry J., Paul D. Kimmel, 2012) . Return on asset merupakan rasio keuangan yang digunakan untuk menilai keseluruhan profitabilitas sebuah perusahaan dari sudut tingkat pengembalian aktiva (Stice, 2004). Semakin rendah rasio return on asset maka semakin kurang baik, demikian pula sebaliknya semakin tinggi rasio return on asset maka semakin baik. Sesuai dengan prinsip pecking order theory bahwa perusahaan yang memiliki return on assets tinggi akan dapat memanfaatkan laba ditahan untuk mendanai operasional perusahaan. Hal ini mendukung penelitian yang dilakukan menunjukkan bahwa profitability teruji negatif terhadap struktur modal (Kakilli Acaravci, 2015). Hubungan negatif ini dapat terjadi karena perusahaan dengan tingkat profitabilitas yang tinggi akan menggunakan laba yang ditahan sebagai modal dari pada hutang dengan pihak eksternal.

H2 : Peningkatan profitabilitas dapat memprediksi penurunan struktur modal.

\section{Risiko Bisnis}

Modigliani dan Miller menganggap bahwa risiko kebangkrutan, biaya transaksi dan manfaat perlindungan pajak merupakan faktor potensial yang meningkatkan keputusan struktur modal (Myers, 2001). Hasil studi Castania menunjukkan bahwa perusahaan yang mempertimbangkan risiko kebangkrutan menggunakan lebih sedikit utang dalam modal struktur karena risiko meningkat. Ini menggambarkan bahwa peningkatan risiko kebangkrutan menyebabkan perusahaan semakin berhati-hati dan akan mengurangi penggunaan proporsi utang dalam komposisi struktur modalnya (Alnajjar, 2015). Sesuai dengan pecking order theory, tingkat risiko yang tinggi kemungkinan akan mengalami kesulitan finansial. Risiko perusahaan ditanggung oleh perusahaan karena adanya ketidakpastian lingkungan bisnis (Alnajjar, 2015). Selanjutnya hasil penelitiannya menunjukkan bahwa risiko bisnis berkorelasi negatif dengan struktur modal. Dengan demikian terdapat indikasi bahwa risiko bisnis memiliki pengaruh terhadap struktur modal.

H3 : Peningkatan risiko bisnis dapat memprediksi penurunan struktur modal. 


\section{METODE PENELITIAN}

Penelitian ini merupakan penelitian kuantitatif karena menggunakan data yang berupa angka-angka pada analisis statistik. Dalam penelitian kuantitatif ini bersifat penelitian deskriptif karena penelitian ini bertujuan untuk menganalisis variabel independen dalam memprediksi variabel dependen. Dalam penelitian ini variabel dependen yang digunakan adalah struktur modal, sedangkan variabel independennya adalah liquiditas, profitablitas dan risiko bisnis.

Penelitian ini menggunakan data sekunder berupa laporan keuangan yang dipublikasikan di website resmi Bursa Efek Indonesia.

\section{Populasi dan Sampel Penelitian}

Populasi dalam penelitian ini adalah perusahaan sub sektor perkebunan yang terdaftar di Bursa Efek Indonesia (BEI) tahun 2012-2016. Teknik pengambilan sampel adalah purposive sampling yaitu teknik penentuan sampel dengan pertimbangan tertentu (Ghozali, 2016). Adapun kriteria dalam penelitian ini adalah perusahaan sub sektor perkebunan yang mempublikasikan laporan keuangan lengkap selama periode pengamatan yaitu tahun 2012-2016. Berdasarkan kriteria tersebut perusahaan yang menjadi sampel penelitian ini sebanyak 11 perusahaan dari 16 perusahaan sub sektor konstruksi bangunan yang terdaftar di Bursa Efek Indonesia.

\section{Operasionalisasi Variabel}

Variabel yang digunakan dalam penelitian ini terdiri atas variabel independen yaitu liquiditas yang diproxikan dalam current ratio, profitabilitas yang diproxikan dalam return on asset, dan risiko bisnis. Sedangkan variabel dependen yaitu struktur modal. Pengukuran operasional merupakan penjelasan pengertian teoritis variabel sehingga dapat diamati dan diukur dalam menganalisis data yang telah dikumpulkan dalam penelitian ini.

Tabel 1

Tabel Operasionalisasi Variabel

\begin{tabular}{|c|c|c|c|}
\hline VARIABEL & INDIKATOR & SKALA & SUMBER \\
\hline $\begin{array}{l}\text { Struktur Modal } \\
\text { (Y) }\end{array}$ & $=\frac{\text { Utang Jangka Panjang }}{\text { Modal Sendiri }}$ & Rasio & (Myers, 2001) \\
\hline $\begin{array}{l}\text { Profitabilitas } \\
\text { (X1) }\end{array}$ & $=\frac{\text { Laba Bersih }}{\text { Total Asset }}$ & Rasio & Weygandt, et.al (2012), \\
\hline $\begin{array}{l}\text { Liquiditas } \\
\text { (X2) }\end{array}$ & $=\frac{\text { Curret Assets }}{\text { Current Liabilities }}$ & Rasio & $\begin{array}{c}\text { (Weygandt, Jerry J., Paul D. } \\
\text { Kimmel. 2012) }\end{array}$ \\
\hline $\begin{array}{l}\text { Risiko Bisnis } \\
\text { (X3) }\end{array}$ & $=\frac{\propto \text { EBIT }}{\text { Total Asset }}$ & Rasio & (Brigham, 2011) \\
\hline
\end{tabular}




\section{Teknik Pengujian Data}

Penelitian ini menggunakan alat analisis regresi berganda. Pengujian data menggunakan program Statistical Product and Service Solution (SPSS) versi 20 dan Microsoft Excel 2007. Pengujian terdiri dari uji asumsi klasik, uji korelasi, uji hipotesis.

\section{HASIL DAN PEMBAHASAN}

\section{Statistik Deskriptif}

Tabel 2 menunjukkan statistik deskriptif variabel penelitian. Variabel struktur modal memiliki nilai rata-rata sebesar 0,8945 dan standar deviasinya sebesar 0,64224. Variabel Liquiditas memiliki rata-rata sebesar 1,0744 dan standar deviasi 0,69988, Profitabilitas memiliki rata-rata sebesar 0,0698 dan standar deviasinya sebesar 0,27941. Risiko Bisnis memiliki rata-rata sebesar 0,0349 dan standar deviasinya sebesar 0,04566. Data penelitian berjumlah 55 .

Tabel 2

Analisis Statistik Deskriptif

\begin{tabular}{|l|r|r|c|}
\hline \multicolumn{1}{|c|}{ VARIABEL } & MEAN & $\begin{array}{c}\text { STANDAR } \\
\text { DEVIASI }\end{array}$ & N \\
\hline Stuktur Modal & 0,8945 & 0,64224 & 55 \\
Liquditas & 1,0744 & 0,69988 & 55 \\
Profitabilitas & 0,0698 & 0,27941 & 55 \\
Risiko Bisnis & 0,0349 & 0,04566 & 55 \\
\hline
\end{tabular}

\section{Uji Asumsi Klasik}

Untuk mengetahui ada tidaknya normalitas residual, multikolinearitas, autokorelasi dan heteroskedatisitas, pada model regresi. Model regresi linear dapat disebut sebagai model yang baik jika model tersebut memenuhi beberapa asumsi klasik yaitu data residual terdistribusi normal, tidak adanya multikolinieritas, autokorelasi, dan heteroskedastisitas.

\section{Uji Normalitas}

Berdasarkan Output SPSS uji Normalitas Gambar 2 dan 3 dapat dilihat bahwa data yang ada merupakan pola distribusi mendekati normal. Hal ini dapat dilihat dari pola kurva distribusi yang memiliki kemiringan cenderung seimbang sisi kiri dan kanan, tidak condong ke kiri ataupun ke kanan, melaikan ke tengah membentuk seperti lonceng, hal ini berarti data residual mempunyai distribusi yang normal (Gambar 1). 


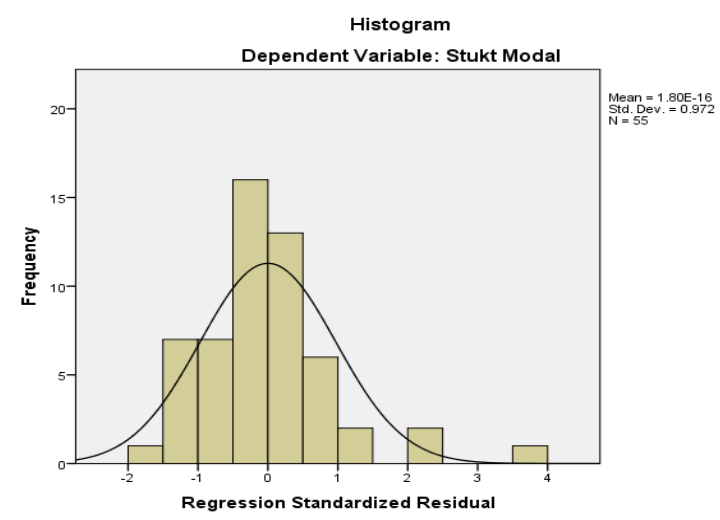

\section{Gambar 1}

Histogram Normalitas Data

Sumber : Output SPSS 20

Berdasarkan Output SPSS diagram normalitas P-Plot of Regression Standardized Residual terlihat bahwa data menyebar disekitar garis diagonal dan mengikuti arah garis diagonal menunjukan pola distribusi normal. Dengan demikian, dapat dikatakan model regresi memenuhi asumsi normalitas (Gambar 2).

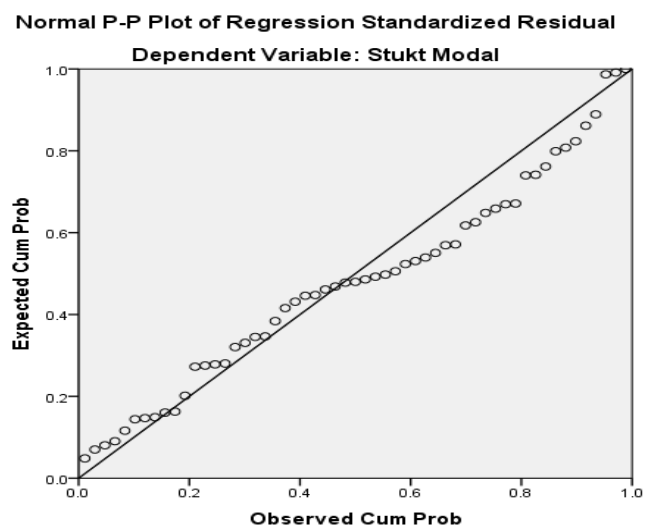

Gambar 2

Normal P-Plot of Regression

Sumber : Output SPSS 20

\section{Uji Multikolinearitas}

Metode pengujian yang bisa digunakan yaitu dengan melihat nilai Variance Inflation Factor (VIF) pada model regresi untuk mengetahui suatu model regresi bebas dari multikolinearitas, yaitu mempunyai nilai VIF kurang dari 10 dan mempunyai angka tolerance dari 0,1 . 


\section{Tabel 3}

Hasil Uji Multikolinearitas

\begin{tabular}{|l|l|r|r|}
\hline \multicolumn{2}{|c|}{ MODEL } & \multicolumn{2}{c|}{ COLLINEARITY STATISTICS } \\
\cline { 3 - 4 } & TOLERANCE & \multicolumn{1}{c|}{ VIF } \\
\hline 1 & & .983 & 1.017 \\
& Liquiditas & 0,948 & 1,055 \\
& Profitabilitas & 0,935 & 1,069 \\
\cline { 3 - 4 } & Risiko Bisnis & Sumber : Output SPSS 20.0
\end{tabular}

Tabel 3 menunjukkan bahwa nilai Tolerance untuk liquiditas sebesar 0,983, profitabilitas sebesar 0,948, risiko bisnis sebesar 0,935. Dengan demikian nilai Tolerance lebih besar dari 0,10 (Tolerance > 0,10). Sedangkan hasil perhitungan nilai Variance Inflation Factor (VIF) untuk liquiditas sebesar 1,017, profitabilitas sebesar 1,055, risiko bisnis sebesar 1,069. Ketiganya mempunyai nilai lebih kecil dari 10 (VIF < 10). Jadi dapat disimpulkan bahwa tidak ada multikolinearitas antar variabel independen dalam model regresi.

\section{Uji Heteroskedastisitas}

Untuk mendeteksi ada tidaknya gejala heteroskedastisitas yaitu dengan melihat gambar grafik scatterplots.

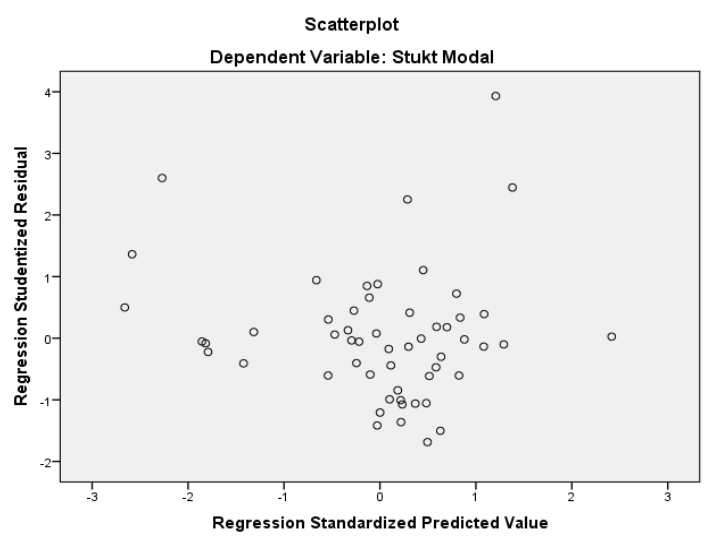

Gambar 3

Scatterplot

Sumber : Output SPSS 20.0

Dari gambar 3 terlihat bahwa tidak ada pola yang jelas, serta titik-titik menyebar diatas dan dibawah angka 0 pada sumbuh $\mathrm{Y}$, maka dapat dikatakan tidak terjadi masalah heteroskedastisitas pada model regresi ini.

\section{Uji Autokorelasi}

Uji autokorelasi bertujuan untuk dapat mengetahui adanya korelasi antara variabel pengaruh pada periode tertentu dengan variabel sebelumnya. Model regresi yang baik adalah regresi yang terbatas dari autokorelasi. 


\section{Tabel 4}

Hasil Pengujian Autokorelasi

\begin{tabular}{|c|c|c|c|c|c|c|}
\hline \multirow[b]{2}{*}{ MODEL } & \multicolumn{5}{|c|}{ CHANGE STATISTICS } & \multirow[b]{2}{*}{$\begin{array}{l}\text { DURBIN- } \\
\text { WATSON }\end{array}$} \\
\hline & $\begin{array}{c}\text { R SQUARE } \\
\text { CHANGE }\end{array}$ & $\begin{array}{c}\text { F } \\
\text { CHANGE }\end{array}$ & DF1 & DF2 & $\begin{array}{c}\text { SIG. F } \\
\text { CHANGE }\end{array}$ & \\
\hline 1 & .373 & 10.131 & 3 & 51 & .000 & 1.079 \\
\hline
\end{tabular}

Sumber : Output SPSS 20.0 metode Stepwise

Berdasarkan tabel 4 dapat dilihat bahwa nilai Durbin-Watson dari model regresi adalah sebesar 1,079. Nilai tersebut terletak diantara -2 dan +2 maka dapat disimpulkan bahwa data tidak mengalami autokorelasi.

\section{Koefisien Korelasi}

Analisis korelasi bertujuan untuk mengetahui hubungan antara dua variabel dan keeratan hubungan tersebut dinyatakan dalam bentuk koefisien korelasi.

\section{Tabel 5}

\section{Koefisien Korelasi}

\begin{tabular}{|c|c|c|c|c|c|}
\hline & & $\begin{array}{c}\text { Stuktur } \\
\text { Modal }\end{array}$ & Liquiditas & Profitabilitas & $\begin{array}{l}\text { Risiko } \\
\text { Bisnis }\end{array}$ \\
\hline \multirow{4}{*}{$\begin{array}{l}\text { Pearson } \\
\text { Correlation }\end{array}$} & Stuktur & 1,000 & $-0,550$ & $-0,277$ & 0,224 \\
\hline & Liquiditas & $-0,550$ & 1,000 & 0,058 & $-0,128$ \\
\hline & Profitabilitas & $-0,277$ & 0,058 & 1,000 & $-0,227$ \\
\hline & Risiko Bisnis & 0,224 & $-0,128$ & $-0,227$ & 1,000 \\
\hline \multirow[t]{4}{*}{ Sig. (1-tailed) } & $\begin{array}{l}\text { Stuktur } \\
\text { Modal }\end{array}$ & & 0,000 & 0,020 & 0,050 \\
\hline & Liquiditas & 0,000 & & 0,338 & 0,176 \\
\hline & Profitabilitas & 0,020 & 0,338 & & 0,048 \\
\hline & Risiko Bisnis & 0,050 & 0,176 & 0,048 & \\
\hline
\end{tabular}

Berdasarkan Tabel 5 dapat diketahui bahwa dengan signifikansi 0,000<0,05, menunjukan terjadi korelasi signifikan antara liquiditas dengan struktur modal. Korelasi -0,550 artinya memiliki tingkat hubungan korelasi kuat dengan hubungan negatif, yaitu apabila liquiditas naik maka struktur modal akan turun dan sebaliknya apabila liquiditas turun makan struktur modal akan naik. Korelasi profitabilitas dengan struktur modal dengan tingkat signifikan 0,002<0,05, menunjukan bahwa terjadi korelasi yang signifikan antara profitabilitas dengan struktur modal. Korelasi sebesar $-0,277$ artinya memiliki tingkat hubungan korelasi cukup dengan arah hubungan negatif, yaitu apabila profitabilitas naik maka struktur modal akan turun dan sebaliknya apabila profitabilitas turun maka struktur modal akan naik. Korelasi risiko bisnis dengan struktur modal dengan tingkat signifikan $0,05=0,05$, menunjukan bahwa tidak terjadi korelasi yang signifikan antara risiko bisnis dengan struktur modal. 


\section{Uji Koefisien Determinasi}

Koefisien determinasi menunjukan seberapa besar kemampuan variabel independen dalam menerangkan variasi variabel dependen sebagai nilai koefisien determinasi.

Tabel 6

Koefisien Determinasi

\begin{tabular}{|c|c|c|c|c|}
\hline MODEL & $\mathbf{R}$ & R SQUARE & $\begin{array}{l}\text { ADJUSTED } \\
\text { R SQUARE }\end{array}$ & $\begin{array}{l}\text { STD. ERROR OF THE } \\
\text { ESTIMATE }\end{array}$ \\
\hline 1 & $.611^{\mathrm{a}}$ & .373 & .337 & .52312 \\
\hline
\end{tabular}

Tabel 6 menunjukkan nilai adjusted $R$ square sebesar 0,337 atau 33,7\%. Koefisien menunjukan bahwa variasi struktur modal dapat dijelaskan oleh variasi variabel independen sebesar 33,7 \%. Jadi sisanya sebesar 66,3\% disebabkan oleh variabel lain diluar dari penelitian ini. Sebagai contoh variabel pertumbuhan, struktur aktiva, ukuran perusahaan.

\section{Uji Hipotesis}

\section{Uji t}

Uji t dilakukan untuk menguji apakah terdapat masing-masing variabel independen dapat memprediksi variabel dependen. Kriteria pengujian dengan membandingkan tingkat signifikansi sebesar 0,05 sebagai berikut :

- Jika probabilitas (sig. penelitian) $>0,05$ maka $\mathrm{H}_{0}$ diterima $\mathrm{H}_{1}$ ditolak

- Jika probabilitas (sig. penelitian) $<0,05$ maka $\mathrm{H}_{0}$ ditolak $\mathrm{H}_{1}$ diterima

Tabel 7

Koefisien Regresi Variabel Independen

\begin{tabular}{|c|c|c|c|c|c|}
\hline & \multirow[t]{2}{*}{ MODEL } & \multicolumn{2}{|c|}{$\begin{array}{c}\text { UNSTANDARDIZED } \\
\text { COEFFICIENTS }\end{array}$} & \multirow[t]{2}{*}{$\mathbf{T}$} & \multirow[t]{2}{*}{ SIG. } \\
\hline & & $\mathrm{B}$ & Std. Error & & \\
\hline \multirow[t]{4}{*}{1} & (Constant) & 1,394 & 0,150 & 9,311 & 0,000 \\
\hline & Liquiditas & $-0,481$ & 0,103 & $-4,685$ & 0,000 \\
\hline & Profitabilitas & $-0,511$ & 0,262 & $-1,952$ & 0,045 \\
\hline & Risiko Bisnis & 1,494 & 1,612 & 0,926 & 0,359 \\
\hline
\end{tabular}

Tabel 7 menunjukkan bahwa variabel liquiditas memiliki sig 0,000, lebih kecil dari 0,05 sehingga dapat dinyatakan bahwa $\mathrm{H}_{0}$ ditolak dan $\mathrm{H}_{1}$ diterima. Artinya liquiditas dapat teruji mampu memprediksi struktur modal. Variabel profitabilitas memiliki sig 0,045, lebih kecil dari 0,05 sehingga dapat dinyatakan bahwa $\mathrm{H}_{0}$ ditolak dan $\mathrm{H}_{2}$ diterima. Artinya profitabilitas teruji mampu 
memprediksi struktur modal. Variabel risiko bisnis memiliki sig 0,823, lebih besar dari 0,05 sehingga dapat dinyatakan bahwa $\mathrm{H}_{0}$ diterima dan $\mathrm{H}_{3}$ ditolak. Artinya risiko bisnis tidak mampu memprediksi struktur modal.

\section{Goodness of Fit (Uji-F)}

Uji Goodness of Fit suatu uji kelayakan model yang digunakan untuk mengukur ketepatan fungsi regresi sampel dalam menaksir nilai aktual.

Kriteria pengujian dengan membandingkan tingkat signifikansi sebesar 0,05 sebagai berikut :

- Jika probabilitas (sig. penelitian) $>0,05$ maka model dinyatakan tidak layak.

- Jika probabilitas (sig. penelitian) $<0,05$ maka model dinyatakan layak.

Tabel 8 menunjukkan tingkat signifikansi $0,000<0,05$, maka dapat dinyatakan bahwa model persamaan regresi dalam penelitian ini layak digunakan.

Tabel 8

Uji F

\begin{tabular}{|l|r|r|r|c|c|}
\hline MODEL & SUM OF SQUARES & DF & MEAN SQUARE & F & SIG. \\
\hline Regression & 8.317 & 3 & 2.772 & 10.131 & $.000^{\mathrm{b}}$ \\
Residual & 13.956 & 51 & .274 & & \\
Total & 22.274 & 54 & & & \\
\hline
\end{tabular}

a. Dependent Variable: Stukt Modal

b. Predictors: (Constant), RISK, LIQ, PROFIT

Sumber : Output SPSS 20.0 Metode Stepwise

\section{E. PEMBAHASAN}

Pertama, hasil penelitian menunjukkan $\mathrm{H}_{0}$ ditolak dan $\mathrm{H}_{1}$ diterima dengan arah koefisien negatif. Hal ini membuktikan bahwa hipotesis pertama yang menyatakan bahwa peningkatan liquiditas memprediksi penurunan struktur modal pada perusahaan sub sektor perkebunan yang terdaftar di Bursa Efek Indonesia periode 2012-2016 telah teruji. Koefisien negatif mencerminkan bahwa apabila liquiditas mengalami peningkatan maka Struktur Modal akan mengalami penurunan. Pecking order theory menyatakan bahwa perusahaan akan lebih memilih menggunakan pendanaan dari internal perusahaan. Jika perusahaan memiliki liquiditas yang tinggi menandakan bahwa perusahaan akan memiliki dana internal yang cukup. Perusahaan lebih memilih menggunakan dana internalnya terlebih dahulu untuk membiayai perusahaannya dan mengurangi hutang sehingga struktur modal menurun. Hasil penelitian ini konsisten dengan penelitian sebelumnya, yang menunjukkan bahwa liquiditas berkorelasi negatif dengan struktur modal (Šarlija \& Harc, 2012).

Kedua, hasil penelitian menunjukkan $\mathrm{H}_{0}$ ditolak dan $\mathrm{H}_{2}$ diterima dengan arah koefisien negatif. Hal ini membuktikan bahwa hipotesis pertama yang menyatakan bahwa peningkatan profitabilitas memprediksi penurunan struktur modal pada perusahaan sub sektor Perkebunan yang terdaftar di Bursa Efek 
Indonesia periode 2012-2016 telah teruji. Koefisien negatif mencerminkan bahwa apabila profitabilitas mengalami peningkatan maka struktur modal akan mengalami penurunan. Pecking order theory menyatakan bahwa perusahaan akan lebih memilih menggunakan pendanaan dari internal perusahaan. Jika perusahaan memiliki profitabilitas yang tinggi menandakan bahwa perusahaan mampu meningkatkan laba ditahan sehingga equitas akan meningkat. Dengan demikian perusahaan akan memiliki dana internal yang cukup. Perusahaan lebih memilih menggunakan dana internalnya terlebih dahulu untuk membiayai perusahaannya dan mengurangi hutang sehingga struktur modal menurun. Hasil penelitian ini konsisten dengan penelitian sebelumnya, yang menunjukkan bahwa profitabilitas teruji dalam memprediksi secara negatif struktur modal (Kakilli Acaravci, 2015).

Ketiga, Kedua, hasil penelitian menunjukkan $\mathrm{H}_{0}$ diterima dan $\mathrm{H}_{3}$ ditolak. Hal ini membuktikan bahwa hipotesis pertama yang menyatakan bahwa peningkatan risiko bisnis memprediksi penurunan struktur modal pada perusahaan sub sektor Perkebunan yang terdaftar di Bursa Efek Indonesia periode 2012-2016 tidak teruji. Hal ini berarti risiko bisnis tidak mampu memprediksi struktur modal. Risiko bisnis merupakan ketidakpastian yang dihadapi perusahaan dan sulit untuk diprediksi hasilnya. Di sisi lain perusahaan yang berani meningkatkan risiko akan berani pula menambah hutang. Perusahaan dengan risiko bisnis yang tinggi akan kesulitan dalam menentukan target laba karena labanya cenderung fluktuatif. Hasil penelitian ini tidak konsisten dengan penelitian yang menghasilkan kesimpulan atas studi empirisnya bahwa risiko bisnis berkorelasi negatif dengan struktur modal pada perusahaan sektor industry di Yordania (Alnajjar, 2015).

\section{F. SIMPULAN}

Berdasarkan hasil penelitian diperoleh simpulan sebagai berikut : liquiditas dan profitabilitas dapat memprediksi struktur modal, sedangkan risiko bisnis tidak dapat memprediksi perubahan struktur modal.

Penelitian ini diharapkan dapat berguna sebagai bahan pertimbangan dan acuan untuk pihak manajemen perusahaan dalam menentukan sumber pendanaan yang terbaik bagi Perusahaan Sub Sektor Perkebunan, karena baik buruknya Struktur Modal akan mempunyai efek langsung terhadap posisi keuangan perusahaan. Oleh karena itu sebaiknya manajemen perlu memperhatikan variabelvariabel yang mempengaruhi Struktur Modal, khususnya uktuk variabel liquiditas dan profitabilitas. Kedua variabel tersebut teruji memiliki kemampuan dalam memprediksi struktur modal, sehingga perusahaan dapat menentukan sumber pendanaan yang optimal.

Hasil penelitian ini diharapkan mampu memberikan informasi kepada investor maupun calon investor sebagai bahan pertimbangan untuk pengambilan keputusan dalam melakukan investasi yang tepat dan dapat menguntungkan.

Keterbatasan-keterbatasan pada penelitian ini antara lain variabel-variabel yang diteliti hanya pada liquiditas yang diproxikan dalam current ratio, profitabilitas return on asset, risiko bisnis. Variabel struktur modal sebagai variabel dependen diproxikan dalan long term debt ratio. Perusahaan yang menjadi subyek penelitian terbatas pada perusahaan Sub Sektor Perkebunan dengan periode pengamatan dari tahun 2012-2016. 
Bagi penelitian selanjutnya dengan mengambil topik yang sama disarankan untuk: menambah variabel-variabel independen lain dalam penelitian, karena masih banyak variabel yang dapat mempengaruhi struktur modal seperti struktur aktiva agar penelitian bisa memberi hasil yang lebih baik lagi. Variabel struktur modal sebaiknya diproxikan dalam short term debt ratio dan total debt ratio selain long term debt ratio. Demikian pula liquiditas dan profitabilitas dapat diproxikan secara variatif. Subyek penelitian lebih diperluas pada sub sektor lainnya, seperti sub sektor kehutanan, sub sektor perikanan dan menambah periode penelitian, sehingga data dan hasil penelitian lebih akurat. 


\section{DAFTAR PUSTAKA}

Abeywardhana, D. K. . (2017). Capital Structure Theory: An Overview. $\begin{array}{llll}\text { Accounting and } & \text { Finance Research, }\end{array}$ https://doi.org/10.5430/afr.v6n1p133

Alnajjar, M. I. M. (2015). Business Risk Impact on Capital Structure: A Case of Jordan Industrial Sector. Global Journal of Management and Business Research: C Finance, 15(1).

Brigham, E. F. and J. F. H. (2011). Essentials of Financial Management: DasarDasar Manajemen Keuangan (Kesebelas). Jakarta: Salemba Empat.

Djaddang, S., \& Ghozali, I. (2017). The Role of Business Risk and Non Debt Tax Shields to Debt to Equity Ratio on Pharmacy Listed Companies in Indonesia. International Journal of Economics and Financial Issues, 7(2), 73-80.

Fahmi, I. (2016). Pengantar Manajemen Keuangan Teori dan Soal Jawab. Bandung: Alfabeta.

Gharaibeh, A. M. O. (2015). The determinants of capital structure: empirical evidence from kuwait. European Journal of Business, Economics and Accountancy, 3(6), 1-25.

Ghozali, I. (2016). Aplikasi Analisis Multivariate dengan Program IBM SPSS 23 (8th ed.). Semarang: Badan Penerbit Universitas Diponegoro.

Gitman, L. J. (2012). Principles of Manajerial Finance. United States: Pearson Addison Wesley.

Kakilli Acaravci, S. (2015). ***The Determinants of Capital Structure: Evidence from the Turkish Manufacturing Sector. International Journal of Economics and Financial Issues, 5(1), 158-171. https://doi.org/10.1108/AJEMS-112012-0072

Lim, T. C. (2012). Determinants of Capital Structure Empirical Evidence from Financial Services Listed Firms in China. International Journal of Economics and Finance, 4(3), 191-203. https://doi.org/10.5539/ijef.v4n3p191

Myers, S. C. (2001). Reading 4 Capital Structure.pdf. Journal of Economic Perspectives. https://doi.org/10.1257/jep.15.2.81

Šarlija, N., \& Harc, M. (2012). The impact of liquidity on the capital structure: a case study of Croatian firms. Business Systems Research, 3(1), 30-36. https://doi.org/10.2478/v10305-012-0005-1

Stice, S. J. D. dan S. K. F. (2004). Akuntansi Intermediate. Jakarta: Salemba Empat.

Weygandt, Jerry J., Paul D. Kimmel, D. E. K. (2012). Financial Accounting IFRS Edition. United States of America: John Wiley \& Sons. 